\title{
ОСОБЛИВОСТІ ДИСТАНЦІЙНОГО НАВЧАННЯ НА КАФЕДРІ ДИТЯЧИХ ХВОРОБ 3 ДИТЯЧОЮ ХІРУРГІЕЮ ТЕРНОПІЛЬСЬКОГО НАЦІОНАЛЬНОГО МЕДИЧНОГО УНІВЕРСИТЕТУ ІМЕНІ І. Я. ГОРБАЧЕВСЬКОГО МОЗ УКРАЇНИ (АНАЛІЗ РЕЗУЛЬТАТІВ АНКЕТУВАННЯ СТУДЕНТІВ)
}

\author{
O. M. Mochulska \\ I. Horbachevsky Ternopil National Medical University

\begin{abstract}
PECULIARITIES OF DISTANCE LEARNING AT THE DEPARTMENT OF THE CHILDREN'S DISEASES WITH PEDIATRIC SURGERY OF (ANALYSIS OF THE RESULTS OF THE STUDENTS SURVEY)
\end{abstract} \\ I. HORBACHEVSKY TERNOPIL NATIONAL MEDICAL UNIVERSITY
}

\begin{abstract}
Анотація. Технології дистанційного навчання стали невід’ємною частиною освітнього процесу сучасного покоління викладачів і студентів, у тому числі у медичних вищих навчальних закладах України, за складних протипандемічних умов, що обумовило напрямок даного дослідження, а саме аналіз думки студентів медичних вузів щодо використання дистанційного навчання в умовах карантину під час пандемії COVID-19. Мета дослідження - проаналізувати результати анонімного он-лайн анкетування студентів 2-3 курсів медичного факультету ТНМУ щодо виправдання власних сподівань у відношенні до якості підготовки лікарів при дистанційному навчанні під час вивчення педіатричних дисциплін, що дозволить оцінити формат он-лайн викладання 3 позиції студентів. Для реалізації даної мети було проведено анонімне он-лайн анкетування вітчизняних студентів 2-3 курсів $(\mathrm{n}=42)$ медичного факультету ТНМУ за допомогою платформи Google Form. Аналіз та узагальнення результатів анонімного он-лайн анкетування констатували наявність різного рівня оцінювання (від 1 до 10 балів) такої складової, як виправдання власних сподівань щодо якості підготовки в дистанційному форматі, - інтерквартильний розподіл середньої становив 9,0 балів, але якість рівня покращення власних практичних компетенцій - лише 6,0 балів. Найчастішою пропозицією для покращення якості навчання, на думку студентів 2-3 курсів медичного факультету, є збільшення можливостей для відпрацювання практичних навичок та професійних компетенцій, які вивчаються. Переважна більшість студентів 2-3 курсів медичного факультету ТНМУ вважає позитивним досвідом навчання в дистанційному форматі, розцінюючи його як можливість для безперервного саморозвитку та самостійного поглиблення теоретичної бази знань, вважаючи його зручним і доступним, індивідуалізованим, прозорим із можливістю незалежного оцінювання. Опитані студенти вважають, що дистанційна форма навчання при вивченні педіатричних дисциплін може бути адаптованим доповненням до аудиторної форми, але не як самостійна форма навчання, оскільки специфіка професії лікаря пов’язана з необхідністю засвоєння і вдосконалення практичних навичок та професійних компетенцій. Технології дистанційного навчання в системі вищої медичної освіти актуальні в наш час і повинні постійно вдосконалюватися, шляхом використання сучасних освітніх цифрових платформ, якісного методичного контентного наповнення web-ресурсів, запровадження ефективної системи контролю якості отриманих знань, щоб сприяти адаптації до нових реалій освітнього процесу та забезпечити високу якість освіти.
\end{abstract}

Ключові слова: дистанційне навчання; медична освіта; аналіз; оцінка; результати анонімного анкетування; анкетування студентів-медиків.

Abstract. Distance learning technologies have become an integral part of the educational process of the current generation of teachers and students, including in medical universities of Ukraine, under difficult anti-pandemic conditions, which led to the direction of this study, namely, the analysis of the medical students opinion on the use of distance learning in quarantine during the COVID-19 pandemic. Purpose of research: to analyze the results of anonymous online questionnaires of the 2-3 years students of the Medical Faculty TNMU, to justify their expectations in relation to the quality of distance learning of pediatric disciplines, which will assess the online teaching format from the perspective of students. To achieve this goal, an anonymous online questionnaire of domestic $2-3$ years stu-

(c) О. М. Мочульська 
dents ( $n=42)$ of the Medical Faculty TNMU was conducted using the Google Form platform. Analysis and synthesis of the results of anonymous online questionnaire found a different level of assessment (from 1 to 10 points) such component as the justification of their own expectations about the quality of training in distance format - interquartile distribution was 9.0 points, but the quality of improving their own practical competencies - only 6.0 points. The most common proposal to improve the quality of education, according to students of 2-3 years of the Medical Faculty TNMU, is to increase opportunities for practical skills and professional competencies that are studied. The vast majority of 2-3 year students of TNMU Medical Faculty consider that it is a positive experience of distance learning, considering it as an opportunity for continuous self-development and independent deepening of the theoretical knowledge base, considering it convenient and accessible, individualized, transparent with independent assessment. Corresponding students believe that distance learning of pediatric disciplines can be adapted to complement the classroom form, but not an independent form of education, as the specifics of the medical profession is need to learn and improve practical skills and competencies. Distance learning technologies in the system of higher medical education are actual nowadays and should be constantly improved through the using of modern digital educational platforms, high-quality methodological content of web-resources, introduction of an effective quality control system to facilitate adaptation to new realities of educational process and to ensure high quality education.

Key words: distance learning; medical education; analysis; assessment; results of anonymous questionnaire; questionnaire of medical students.

Вступ. Дистанційне навчання - це форма навчання, яка вимагає використання комп’ютерних й інформаційно-комунікаційних технологій, що забезпечують можливість навчатися на відстані без особистого контакту між викладачами та студентами, інтерактивну взаємодію викладачів і студентів на різних етапах навчання й самостійну роботу 3 матеріалами інформаційної мережі. Дистанційне навчання - це технологія, що базується на принципах відкритого навчання, широко використовує комп'ютерні навчальні програми різного призначення і створює за допомогою сучасних телекомунікацій інформаційне освітнє середовище для постачання навчального матеріалу та спілкування. За таких умов акцент у навчанні зміщується на самостійну роботу студента, а викладач виступає переважно в ролі організатора навчального процесу, консультанта. Основними варіантами, доступними для навчання за дистанційної освіти, є такі традиційні форми освітньої підготовки, як лекція, практичне заняття, семінар, консультація, що відповідають чинному законодавству [2, 4, 6, 8-10].

Дистанційне навчання має ряд переваг та недоліків щодо зручності освітнього процесу для викладачів та студентів, проте сучасні реалії життя вимагають широкого використання цієї форми медичної освіти.

У наш час дистанційне навчання $є$ однією 3 провідних світових тенденцій в освіті, технологією, яка реалізує принцип безперервної освіти і здатна задовольнити постійно зростаючий попит на знання в інформаційному суспільстві, маючи при цьому низку переваг. Дистанційне навчання не лише активно використовується в усьому світі, наприклад, відома Global Distance Education Network (GDENET), але вдосконалюється й розвивається. Дистанційне навчання на основі дистанційних освітніх платформ забезпечує особис- тісно-орієнтоване і безперервне, якісне та всебічне навчання у найбільш зручному місці й часі без відриву від повсякденної діяльності, доступ до електронних баз знань, суттєво підвищує активну роль студентів у процесі навчання, вимагає від викладачів вдосконалення викладання як за змістом, так і за його формою. Також до переваг дистанційного навчання можна віднести високу ефективність професійної підготовки, короткий термін навчання, незалежність студента від територіального розташування вищого навчального закладу, можливість одночасно навчатися як у вітчизняних, так і в зарубіжному вузах, постійний доступ до джерел інформації [1, 3, 7, 8, 11].

Серед основних недоліків дистанційного навчання варто відмітити: відсутність практичних занять, для яких потрібна якісна техніка та Internetзв'язок, відсутність постійного контролю, відсутнє безпосереднє спілкування викладача і студента, у навчанні немає індивідуального підходу, у студентів не завжди є самодисципліна, свідомість і самостійність, які необхідні для дистанційного навчання, запропоновані студенту завдання, для перевірки знань, можуть допомагати виконувати інші [1, 3, 7, 8, 11].

Спілкування та обстеження пацієнтів необхідні для вивчення та побудови діагностики клінічного мислення майбутнього лікаря. В якості альтернативи пацієнт-орієнтованого навчання можуть бути використані клінічні стажування, з використанням Internet-мережi, web-ресурсів у режимі он-лайн, відеозаписів або трансляцій пацієнтів, клінічних випадків, консиліумів лікарів, тренінгів і майстеркласів через комп'ютерний зв'язок (телемедицина). Водночас взаємодія між студентом і пацієнтом $€$ необхідною складовою, а всі запропоновані методи не замінюють фактичний контакт із пацієнтом, тому пошук та освоєння інноваційних форм і ме- 
тодів дистанційної освіти є питанням важливим для медичних навчальних закладів [3, 5, 6, 9, 10].

Варто відмітити, що самостійній роботі студента при дистанційному навчанні приділяється значно більше уваги. Самостійна робота студента передбачає роботу з освітнім матеріалом для практичних, семінарських занять і лекцій з окремої дисципліни, а також додаткове тематичне навчання за допомогою представлених у мережі Internet освітніх платформ для самостійного навчання (Coursera, Prometheus, eDX, TedED, EdEra та KhanAcademy). Альтернативними формами надання доступу до інформації можуть бути власні інформаційні бази, сукупність web-ресурсів, власний web-сайт університету і кафедри, Internet-сайти із завантаженими текстовими документами, відео- і аудіофайлами, використання розсилки через індивідуальні поштові скриньки студентам [2, 3, 4, 6, 9].

Завдання викладачів у випадку імплементації дистанційного навчання включають надання студентам доступу до електронних баз даних навчального матеріалу та моніторування успішності засвоєння ними матеріалів навчальної дисципліни протягом усього періоду навчання. За умов дистанційного навчання важливим аспектом роботи викладачів є удосконалення як змісту, так і форми подання навчальних матеріалів. Викладачі повинні стежити за тим, щоб зміст цих матеріалів відповідав необхідному освітньо-кваліфікаційному рівню та спеціальності, у нашому випадку рівням «Спеціаліст» і «Магістр» за спеціальностями «Лікувальна справа» та «Медицина» відповідно до державних стандартів освіти й існуючих затверджених навчальних планів та програм викладання педіатричних дисциплін на різних курсах. Підготовка та оформлення навчальних матеріалів повинні бути згідно з державними стандартами освіти [2, 4, 5, 6, 10, 11].

Сьогодні глобальна світова проблема, яка виникла у зв’язку з розповсюдженням вірусної інфекції COVID-19, призвела до необхідності проведення дистанційного навчання у вищих навчальних закладах. Пандемія коронавірусу COVID-19 та запроваджений карантин змусили всі країни переглянути освітні стратегії навчання. Технології дистанційного навчання стали невід'ємною частиною освітнього процесу сучасного покоління викладачів і студентів, у тому числі у медичних вищих навчальних закладах України, за складних протипандемічних умов, що обумовило напрямок даного дослідження, а саме аналіз думки студентів медичних вузів щодо використання дистанційного навчання в умовах карантину під час пандемії COVID-19 [1, 2, 4, 5, 12].

Мета дослідження - проаналізувати результати анонімного он-лайн анкетування студентів 2-3 курсів медичного факультету ТНМУ щодо виправдання власних сподівань у відношенні до якості підготовки лікарів при дистанційному навчанні під час вивчення педіатричних дисциплін, що дозволить оцінити формат он-лайн викладання з позиції студентів.

Методи дослідження. Проведено анонімне он-лайн опитування серед вітчизняних студентів 2-3 курсів медичного факультету ТНМУ за допомогою платформи Google Form. Загалом проанкетовано 42 студенти. Були використані анкетування та статистичний методи дослідження. Опитування складалося з 15 питань, що включали відкриті питання, альтернативні питання, питання з можливістю надати оцінку в наведеному діапазоні (від 1 до 10 балів).

Інформована згода була отримана під час проведення опитування, включена в Google Form. Учасники визнали, що їх участь була добровільною. Респонденти були проінформовані про причини, за якими була зібрана інформація та як вона буде використана, що їх відповіді анонімні та конфіденційні. Дослідження було виконано відповідно до принципів Гельсінської декларації.

Статистична обробка матеріалу та аналіз результатів здійснювалися за допомогою стандартних алгоритмів варіаційної статистики, для розрахунків використовувалися комп’ютерна програма Excel (Microsoft Office, USA) та Statistica StatSoft 6.0 й on-line калькулятор SISA (Simple Interactive Statistical Analysis), розраховували t-критерій Стьюдента або критерій $\chi 2$ (різниця вважалася вірогідною при $\mathrm{p} \leq 0,01$ або $\mathrm{p}<0,05)$. Розподіл змінних оцінювали за допомогою тесту $\chi 2$. Для кількісних показників параметри статистики наведені в якості медіани та інтерквартильного розмаху. Статистична оцінка отриманих даних виконана методами параметричної та непараметричної статистики. Аналіз даних проводили з використанням методів описової статистики.

Результати дослідження. Відповідно до отриманих результатів, більшість опитаних вітчизняних студентів 2-3 курсів медичного факультету ТНМУ позитивно сприйняла досвід дистанційного навчання (n=37, 88,0 \%). Особливо цікавим є той факт, що серед респондентів не було студентів, байдужих 
до форми навчання (0 \%), кожен студент сформував власну думку щодо порівняння аудиторного та дистанційного он-лайн навчання, власного досвіду дистанційного навчання (рис. 1).

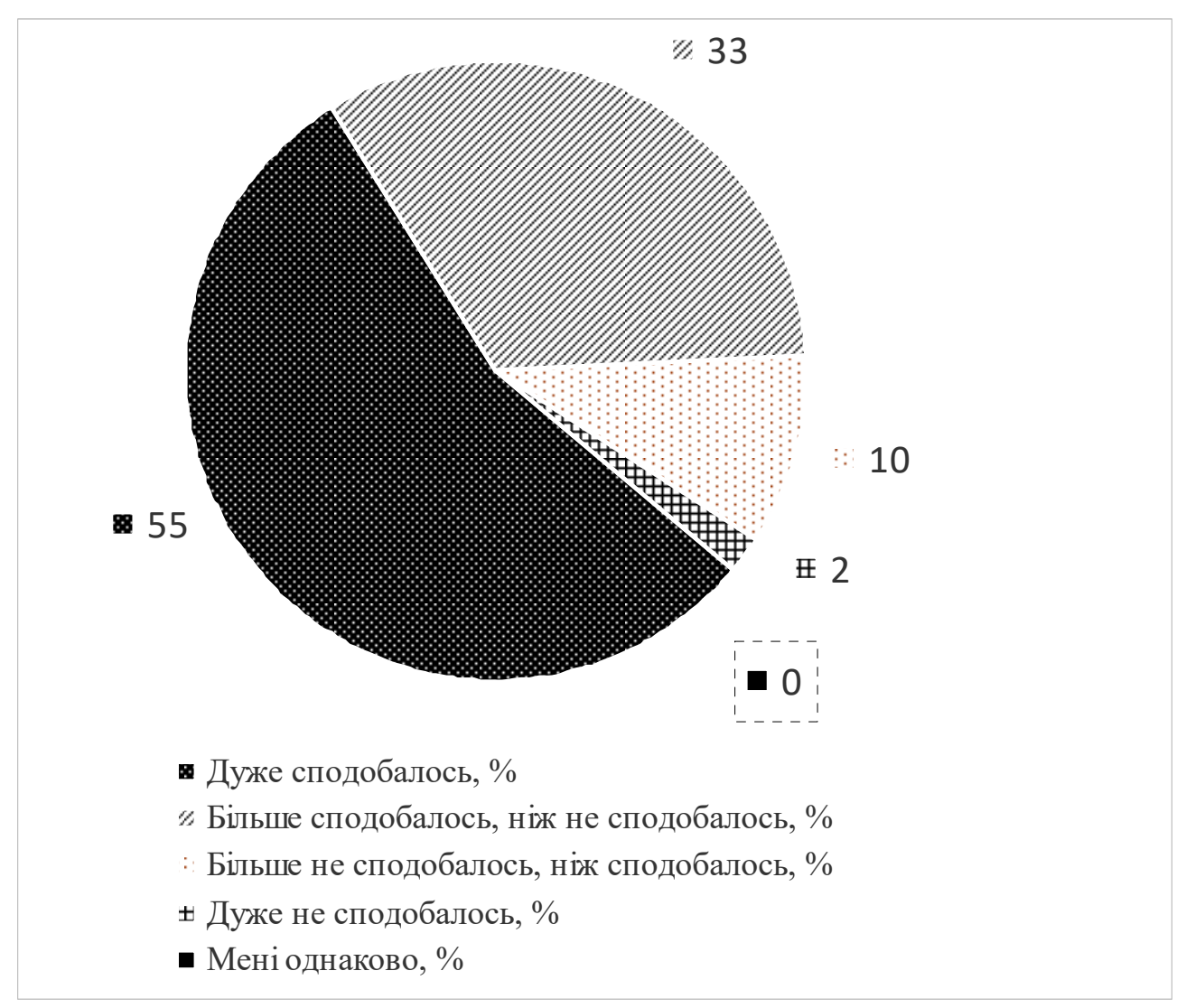

Рис. 1. Загальна оцінка досвіду дистанційного навчання студентами.

Найважливішими перевагами дистанційного навчання студенти вважають такі, як: забезпечує особистісно-орієнтоване та безперервне, якісне та всебічне навчання у найбільш зручному місці і часі без відриву від повсякденної діяльності (n=40, 95,2 \%), підтримує інтерактивну он-лайн взаємодію викладачів та студентів на різних етапах навчання (n=39, 92,8 \%), постійна доступність до джерел інформації, усіх електронних баз знань незалежно від часу та відстані (n=30, 71,4%), гнучкий графік навчання з можливістю коректувати та варіювати темп роботи, достатній час на підготовку і виконання завдання (n=28, 66,6 \%), незалежність студентів від територіального розташування вищого навчального закладу (n=25, 59,5 \%), відсутність потреби витрачати час на дорогу, кошти на проживання та дорогу до навчального закладу (n=26, 61,9\%), самостійна робота студентів із матеріалами інформаційної мережі, стимуляція до творчого, мотивація до особистісного розвитку, а також підвищення рівня самостійності та самоконтролю в про- цесі навчання ( $n=20,47,6$ \%), освоєння телемедицини, технологічні можливості навчання у вигляді відеоконференцій, трансляцій та дискусій у режимі он-лайн (n=11, 26,1%), можливість відчувати себе вдома в безпеці, зважаючи на наявність пандемії COVID-19 (n=9, 21,4 \%). Водночас недоліками дистанційного навчання студенти вважають: відсутнє безпосереднє спілкування викладачів та студентів, пацієнтів і студентів у реалі (n=37, 88,0 \%), збільшення навантаження на студентів самостійних видів робіт із навчальним теоретичним матеріалом, порівняно з аудиторною формою навчання (n=14, 33,3 \%), висока залежність ефективності навчання у студентів від власної самодисципліни, свідомості, самостійності, мобільності і відповідальності (n=13, 30,9 \%), недостатність оволодіння практичними навичками та можливостей відпрацювання компетенцій за підтримки викладачів (n=17, 40,5 \%), залежність від власного технічного оснащення та якості Internet-зв'язку вдома $(\mathrm{n}=7$, 16,6 \%), збільшення кількості тестових та пись- 
мових ситуаційних завдань як форм контролю засвоєння знань (n=4, 9,9 \%).

Відповідно до поставлених задач даного дослідження, проведено аналіз щодо пріоритетної форми навчання на думку студентів. Вподобання респондентів розподілилися таким чином: більшість респондентів серед опитаних студентів надала пе- ревагу змішаній (аудиторно-дистанційній) формі навчання (n=23, 55,0 \%), значна кількість студентів надала перевагу аудиторній формі навчання (n=16, 38,0 \%), і зовсім незначна кількість у подальшому обрала б для себе виключно дистанційну форму навчання (n=3, 7,0 \%) (рис. 2).

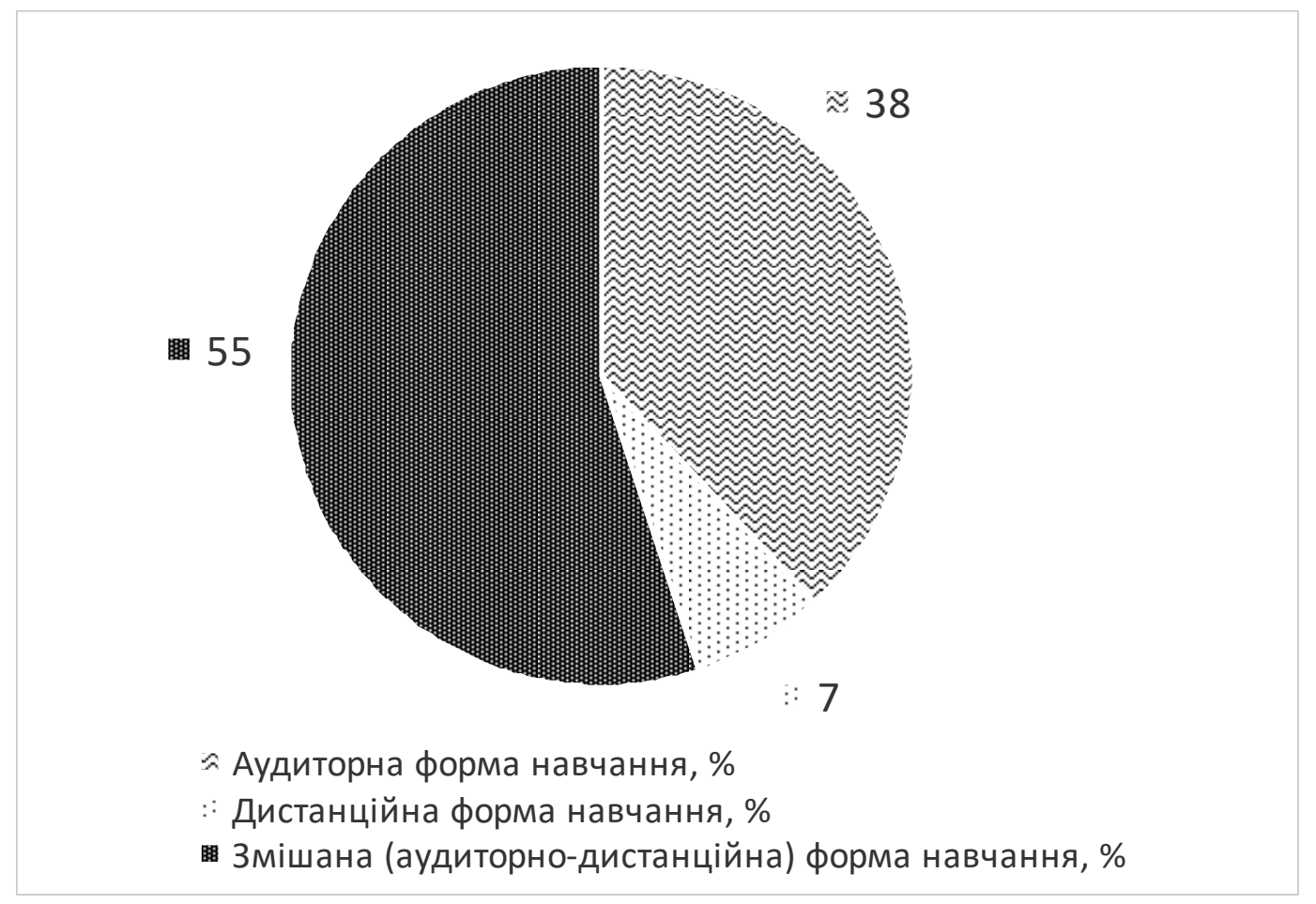

Рис. 2. Розподіл вподобань студентів щодо вибору найбільш оптимальної форми продовження навчання в майбутньому.

Аналіз та узагальнення результатів анонімного анкетування студентів 2-3 курсів медичного факультету ТНМУ констатували наявність різного рівня оцінювання (від 1 до 10 балів) такої складової, як виправдання власних сподівань щодо якості підготовки в дистанційному форматі, - інтерквартильний розподіл середньої становив 9,0 балів, але якість рівня покращення власних практичних компетенцій - лише 6,0 балів. Найчастішою пропозицією для покращення якості навчання, на думку студентів 2-3 курсів медичного факультету ТНМУ, $€$ збільшення можливостей для відпрацювання практичних навичок та професійних компетенцій, які вивчаються на педіатричних дисциплінах, що особливо важливо для майбутніх лікарів.

Висновки та перспективи подальших досліджень. Переважна більшість студентів 2-3 курсів медичного факультету ТНМУ вважає позитивним досвідом навчання в дистанційному форматі, роз- цінюючи його як можливість для безперервного професійного саморозвитку та самостійного поглиблення теоретичної бази знань, вважаючи його зручним і доступним, індивідуалізованим, прозорим із можливістю незалежного оцінювання. Віртуальна мобільність і відсутність кордонів дають можливість здобувати освіту незалежно від локації в будь-якому освітньому закладі світу. Водночас дистанційне навчання не лише розширює можливості для отримання якісної освіти, а й дає змогу урізноманітнити навчальний процес, що також $є$ чинником підвищення інтересу до дисципліни та мотивації. Проанкетовані студенти 2-3 курсів медичного факультету ТНМУ при вивченні педіатричних дисциплін вважають, що дистанційна форма навчання може бути адаптованим доповненням до аудиторної форми, але не як самостійна форма навчання, оскільки специфіка професії лікаря пов’язана з необхідністю засвоєння і вдосконален- 
ня практичних навичок та професійних компетенцій, важливих для майбутніх лікарів.

Технології дистанційного навчання в системі вищої медичної освіти актуальні в наш час та повинні постійно вдосконалюватися, шляхом імплементації новітніх та доступних методів дистанційної освіти, вдосконалення клінічного мислення фахівців із використанням інтерактивних методик навчання, використання сучасних освітніх цифрових платформ, якісного методичного контентного наповнення web-ресурсів, запровадження ефективної системи контролю якості отриманих знань, щоб сприяти адаптації до нових реалій освітнього про-

\section{Список літератури}

1. Боярчук О. Р. Питання медичної етики при вивченні пропедевтики педіатрії / О. Р. Боярчук, О. М. Шульгай, М. І. Кінаш // Медична освіта. - 2019. - № 1. - С. 6-9.

2. Височина І. Л. Дистанційне навчання на кафедрі сімейної медицини Д3 «Дніпропетровська медична академія МОЗ України» очима студентів-медиків другого курсу (аналіз результатів анонімного анкетування) / І. Л. Височина, І. В. Авраменко, Н. С. Башкірова // Медична освіта. - 2020. - № 4. - С. 5-9.

3. Дистанційне навчання як інформаційно-комунікативна технологія додипломної підготовки лікарів з педіатрії в умовах сучасних викликів / О. П. Волосовець, О. В. Виговська, С. П. Кривопустов [та ін.] // Медична освіта. - 2020. - № 3. - С. 9-12.

4. Застосування дистанційної освіти у післядипломній підготовці лікарів-стоматологів в умовах карантинних заходів / О. В. Павленко, Т. М. Волосовець, О. М. Дорошенко [та ін.] // Медична освіта. - 2020. - № 3. - С. 13-16.

5. Кашуба М. О. Нові часи - нові виклики (особливості медичної освіти в нових реаліях) / М. О. Кашуба, С. В. Кучер // Медична освіта. - 2021. - № 1. - С. 136141.

6. Летняк Н. Я. Особливості дистанційного навчання студентів спеціальності «Медсестринство» при вивченні дисципліни «Біологічна хімія» / Н. Я. Летняк, І. П. Кузьмак // Медична освіта. - 2021. - № 1. - С. 29-34.

\section{References}

1. Boiarchuk, O.R., Shulhai, O.M., \& Kinash, M.I. (2019). Pytannia medychnoi etyky pry vyvchenni propedevtyky pediatrii [Medical ethics issues of pediatrics propaedeutics]. Medychna osvita - Medical Education, 1, 6-9 [in Ukrainian].

2. Vysochyna, I.L., Avramenko, I.V., \& Bashkirova, N.S. (2020). Dystantsiine navchannia na kafedri simeinoi medytsyny DZ «Dnipropetrovska medychna akademiia MOZ Ukrainy» ochyma studentiv-medykiv druhoho kursu (analiz rezultativ anonimnoho anketuvannia) [Distance learning at the department of family medicine, Dnipropet- цесу та забезпечити високу якість медичної освіти для майбутніх лікарів.

Перспективою подальших досліджень є розширення аудиторії опитаних студентів (респондентів) для масштабнішого анкетування із залученням вітчизняних та іноземних студентів різних курсів 3 метою вивчення особливостей сприйняття різних форм навчання, більш комплексного системного вивчення їх суб'єктивної оцінки і досвіду дистанційного навчання, порівняння між собою особливостей різних форм навчання залежно від курсу навчання та мови викладання дисциплін.

7. Мельничук I. М. Використання інтерактивних методів навчання у підготовці майбутніх педіатрів до роботи в команді / I. М. Мельничук // Медична освіта. - 2020. - № 4. - С. 43-46.

8. Особливості дистанційного навчання в рамках післядипломної підготовки лікарів з медицини невідкладних станів / А. О. Волосовець, Б. І. Слонецький, І. С. Зозуля [та ін.] // Медична освіта. - 2020. - № 3. - С. 5-8.

9. Переваги і недоліки дистанційного навчання в цілому та при вивченні дисципліни «Гістологія, цитологія та ембріологія» / І. Б. Гетманюк, С. Б. Крамар, 3. М. Небесна, О. Я. Шутурма // Медична освіта. - 2020. - № 4. - С. 16-19.

10. Платонова О. М. Дистанційне навчання при викладанні педіатричних дисциплін: виклики часу / О. М. Платонова, Т. В. Стоєва, О. В. Тіткова // Медична освіта. - 2020. - № 4. - С. 52-56.

11. Посоленик Л. Я. Використання інтерактивних методів викладання та розвиток дистанційної освіти лікарів у Тернопільському національному медичному університеті імені І. Я. Горбачевського МОЗ України в умовах карантину / Л. Я. Посоленик, О. Я. Видойник // Медична освіта. - 2020. - № 4. - С. 80-84.

12. Про затвердження Положення про дистанційне навчання : наказ Міністерства освіти і науки України від 25.04.2013 p. № 466.

rovsk medical academy, Ministry of healthcare of Ukraine, through the eyes of second-year medical students (analysis of the results of the anonymous survey)]. Medychna osvita - Medical Education, 4, 5-9 [in Ukrainian].

3. Volosovets, O.P., Vyhovska, O.V., Kryvopustov, S.P., Kuzmenko, A.Ya., Lohinova, I.O., Chernii, O.F., ... Kovtun, O.V. (2020). Dystantsiine navchannia yak informatsiino-komunikatyvna tekhnolohiia dodyplomnoi pidhotovky likariv z pediatrii v umovakh suchasnykh vyklykiv [Distance learning as an information and 
communicative technology of the undergraduate training of pediatricians in the contemporary challenge]. Medychna osvita - Medical Education, 3, 9-12 [in Ukrainian].

4. Pavlenko, O.V., Volosovets, T.M., Doroshenko, O.M., Doroshenko, M.V., \& Bakshutova, N.O. (2020). Zastosuvannia dystantsiinoi osvity u pisliadyplomnii pidhotovtsi likariv-stomatolohiv v umovakh karantynnykh zakhodiv [Use of distance education in postgraduate training of dentists in the conditions of quarantine measures]. Medychna osvita - Medical Education, 3, 13-16 [in Ukrainian].

5. Kashuba, M.O., \& Kucher, S.V. (2021). Novi chasy - novi vyklyky (osoblyvosti medychnoi osvity v novykh realiiakh) [New times - new challenges (features of medical education in new realities)]. Medychna osvita - Medical Education, 1, 136-141 [in Ukrainian].

6. Letniak, N.Ya., \& Kuzmak, I.P. (2021). Osoblyvosti dystantsiinoho navchannia studentiv spetsialnosti «Medsestrynstvo» pry vyvchenni dystsypliny «Biolohichna khimiia» [Peculiarities of distance learning of students of the specialty "Nursing" in the study of the discipline "Biological chemistry"]. Medychna osvita-Medical Education, 1, 29-34 [in Ukrainian].

7. Melnychuk, I.M. (2020). Vykorystannia interaktyvnykh metodiv navchannia u pidhotovtsi maibutnikh pediatriv do roboty $\mathrm{v}$ komandi [Using interactive methods of study in training of future pediatricians for team work]. Medychna osvita - Medical Education, 4, 43-46 [in Ukrainian].

8. Volosovets, A.O., Slonetskyi, B.I., Zozulia, I.S., Bobrova, V.I., Ivaschenko, O.V., Verbytskyi, I.V., ... Savchenko, D.S. (2020). Osoblyvosti dystantsiynoho navchannia v ramkah pisliadyplomnoi pidhotovky likariv z medytsyny nevidkladnyh staniv [Peculiarities of distance learning within the framework of postgraduate training of doctors in emergency medicine]. Medychna osvita - Medical Education, 3, 5-8 [in Ukrainian].

9. Hetmaniuk, I.B., Kramar, S.B., Nebesna, Z.M., \& Shuturma, O.Ya. (2020). Perevahy i nedoliky dystantsiinoho navchannia $\mathrm{v}$ tsilomu ta pry vyvchenni dystsypliny «Histolohiia, tsytolohiia ta embriolohiia» [Advantages and disadvantages of distance learning in general and in the study of the discipline "Histology, cytology and embryology"]. Medychna osvita - Medical Education, 4, 16-19 [in Ukrainian].

10. Platonova, O.M., Stoieva, T.V., \& Titkova, O.V. (2020). Dystantsiine navchannia pry vykladanni pediatrychnykh dystsyplin: vyklyky chasu [Distance learning in the teaching of pediatric disciplines: the challenge of time]. Medychna osvita - Medical Education, 4, 52-56 [in Ukrainian].

11. Posolenyk, L.Ya., \& Vydoinyk, O.Ya. (2020). Vykorystannia interaktyvnykh metodiv vykladannia ta rozvytok dystantsiinoi osvity likariv u ternopilskomu natsionalnomu medychnomu universyteti imeni I. Ya. Horbachevskoho MOZ Ukrainy v umovakh karantynu [Use of interactive methods of teaching and development of distance education of doctors in I. Horbachevsky Ternopil National Medical University in quarantine conditions]. Medychna osvita Medical Education, 4, 80-84 [in Ukrainian].

12. Nakaz Ministerstva osvity i nauky Ukrainy Pro zatverdzhennia Polozhennia pro dystantsiine navchannia vid 25.04.2013 r. № 466 [Order of the Ministry of Education and Science of Ukraine On approval of the Regulations on distance learning dated 25.04.2013 No. 466] [in Ukrainian]. 